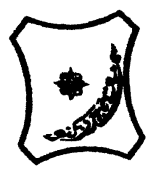

Bayero Journal of Pure and Applied Sciences, 8(2): 117 - 122

Received: November, 2014

Accepted: October, 2015

ISSN 2006 - 6996

\title{
EVALUATION OF THE AFFINITY OF THE COMPONENTS OF BLOOD AND FUR OF ALBINO RAT FOR BIOACCUMULATION OF CHROMIUM (VI) ION FOLLOWING MILD EXPOSURE
}

\author{
Omoniyi K. I. * and Ekwumemgbo A. P. \\ Chemistry Department, Ahmadu Bello University, Zaria, Nigeria. \\ *Correspondence e-mail: israelflourish@yahoo.com \\ *Telephone Number: +234-08036257789
}

\section{Abstract}

The study investigates the affinity of chromium (VI) ion for the components of blood and fur of female albino rats after spaced dosing with $5 \mathrm{~mL}$ and $1 \mathrm{~mL}$ of $1.0 \mu \mathrm{g} / \mathrm{mL} \mathrm{K}_{2} \mathrm{Cr}_{2} \mathrm{O}_{7}$ solution intraperitoneally in May, 2012; for application in forensic analyses following industrial and environmental exposures. The level of total-Cr ions was determined in the serum, red blood cell, plasma and fur of the experimental female albino rats after dosing with $5 \mathrm{~mL}$ of 1.0 $\mu \mathrm{g} / \mathrm{mL} \mathrm{K}_{2} \mathrm{Cr}_{2} \mathrm{O}_{7}$ solution intraperitoneally in day 1 , and $1 \mathrm{~mL}$ of the same solution on day 8 of the experiment, using atomic absorption spectrophotometry. After two weeks of $\mathrm{K}_{2} \mathrm{Cr}_{2} \mathrm{O}_{7}$ administration, $12.127 \pm 0.726 \mu \mathrm{g} / \mathrm{mL}, 2.956 \pm 0.003,2.210 \pm 0.002$ and $4.090 \pm 0.0078$ $\mu \mathrm{g} / \mathrm{mL}$ were the mean levels of ions in the serum, red blood cell (RBC), plasma and fur respectively. There was no significant weight increase in the experimental group compared to the control group during the dosing period; however, the experimental group showed passiveness, consumed less feed, but had more water intake compared to the control group. The ranking for the mean level of total-Cr ions in the experimental rat followed the ranking, serum > fur > red blood cell (RBC) > plasma; while the control had the ranking serum > fur $>$ plasma $>R B C$. There was high statistical increase in the ions in the serum of the experimental rat compared to the control; likewise the level in the experimental fur was highly elevated compared to the control ( $P<0.05)$. The total-Cr ions in the fur and serum were doubled due to the administration of $\mathrm{K}_{2} \mathrm{Cr}_{2} \mathrm{O}_{7}$ solution to the rats. The findings of the study signaled that the fur and serum can equally serve as specimen for detection of mild exposure to $\mathrm{Cr}$ (VI) during forensic investigation.

Key words: albino rat; blood component; chromium (VI) ion; forensic; mild exposure

\section{INTRODUCTION}

Kortenkamp (1997) surveyed the most important chromium-containing materials or objects as: $\mathrm{Cr}$ ore, lubricating oils, artificial dentures, wood preservation salts, cement, and leather tanned with $\mathrm{Cr}$, dust particles beside busy roadways and use of tobacco products. People who work with materials containing mere traces of $\mathrm{Cr}$ salts are more at risk than workers who come into contact with high concentration of $\mathrm{Cr}$ salts (Adya et al., 2005).

Chromium (VI) is the primarily form of $\mathrm{Cr}$ that has been implicated to be harmful to the biosphere (Amoikon et al., 1995). The major emission source of $\mathrm{Cr}(\mathrm{VI})$ is the chrome plating industry. Chromic acid, used to electroplate metal parts, is the most common $\mathrm{Cr}$ (VI) compounds produced; chromic acid is also registered as a fungicide and pesticide in California for use in wood and lumber protection treatments (Kortenkamp, 1997; Becker et al.,1991). Emissions of $\mathrm{Cr}$ (VI) may also result from lead chromate in paint, chromate production, coatings on stainless steel, fuel combustion and auto refinishing. If not all, most of this emitted chromium is in the $\mathrm{Cr}$ (VI) state (Amoikon et al., 1995; Becker et al.,1991).

$\mathrm{Cr}$ (VI) exists as a component of a complex anion that varies with $\mathrm{pH}$ and may take the form of chromate $\left(\mathrm{CrO}_{4}^{-2}\right)$, hydrochromate $\left(\mathrm{HCrO}_{4}^{-}\right)$, or dichromate $\left(\mathrm{Cr}_{2} \mathrm{O}_{7}^{-}\right.$ ${ }^{2}$ ). These ionic $\mathrm{Cr}^{+6}$ forms are highly soluble in water and thus mobile in the aquatic environment or biofluids (Ecological Analysts, 1981).

Accumulations of $\mathrm{Cr}$ in tissues and organism depend heavily on its chemical form, route of entry and amount administered. On exposure of the body to $\mathrm{Cr}(\mathrm{VI})$, the body changes $\mathrm{Cr}$ (VI) to $\mathrm{Cr}$ (III) (Yamaguchi and SanoK, 1983).Cr (III) in biological materials functions in mammals by maintaining efficient glucose, lipid, and protein metabolism (Steven et al., 1976). In general, the toxicity of $\mathrm{Cr}$ (III) to mammals is low because it tends to form stable complexes with negatively charged inorganic or organic compounds in aqueous or particulate form; so its membrane permeability is poor and it is noncorrosive; further, there is little tendency for $\mathrm{Cr}^{+3}$ to biomagnify in food chains in the inorganic form. 
However, the oxidizing potential of $\mathrm{Cr}$ (VI) is high, so it easily penetrates biological membranes and so is more toxic than the +3 form (Steven et al., 1976; Taylor and Parr, 2002; Yasuko et al., 2006). All stable $\mathrm{Cr}^{+6}$ anionic compounds strongly oxidize organic matter on contact and yield oxidized organic matter and $\mathrm{Cr}^{+3}$ (Yasuko et al., 2006).

Toxicity of $\mathrm{Cr}$ (VI) among warm-blooded organisms has been reported, for instance it was fatal to dogs in 3 months at $100 \mathrm{mg} / \mathrm{kg}$ in their food and killed most mammalian experimental animals at injected doses of 1 to $5 \mathrm{mg} \mathrm{Cr} / \mathrm{kg}$ body weight (Ronald, 1986). $\mathrm{Cr}$ (VI) compounds may cause skin ulceration, irritative dermatitis, ulcerations in mucous membranes, and perforations of the nasal septum. That inhalation of $\mathrm{Cr}^{+6}$ compounds may cause bronchial carcinomas has been well documented in humans (Langard and Norseth, 1979). Chromate producing industrial workers developed respiratory cancer after been exposed to 30 to $1,100 \mathrm{ug} / \mathrm{m}^{3} \mathrm{Cr}$ ( VI) in air for periods of 4 to 24 years, and workers producing chromate pigment reportedly developed respiratory cancer after been subjected to an estimated $\mathrm{Cr}^{+6}$ exposure of 500 to $1,500 \mathrm{ug} / \mathrm{m}^{3}$ for 6 to 9 years (Post and Campbell, 1980).

At least three distinct $\mathrm{Cr}^{+6}$ excretion patterns exist in rats: blood has a single component, with a biological half-life of 13.9 days; testes, brain, kidney and lung have two components; and liver has three components with half-lives of $2.4 \mathrm{~h}, 52.8 \mathrm{~h}$ and 15.7 day (Yamaguchi and SanoK, 1983). Cr ion accumulation in organs of albino rats $72 \mathrm{~h}$ after each of the four-weekly intraperitoneal administration of $1.0 \mathrm{~mL}$ of $1.0 \mu \mathrm{g} / \mathrm{mL}$ $\mathrm{K}_{2} \mathrm{Cr}_{2} \mathrm{O}_{7}$ solution and another four weeks of recovery using atomic absorption spectrophotometry indicated that the total $\mathrm{Cr}$ ion in the organs of both sexes of the rat followed the ranking blood $>$ heart $>$ liver; though the male accumulated more (Omoniyi et al., 2010).

Wiegand et al. (1985) described the in vitro uptake kinetics of hexavalent chromium in erythrocytes of rats and humans. Blood sample is the commonest for evaluating systemic accumulation of heavy metal pollutants compared to hair, saliva and urine.The body's excretory mechanisms may eliminate particles and particle breakdown products as substances are transported in the blood or the lymph. So the levels of released toxins such as metal ions may be detected and determined in body fluids such as serum or plasma, urine and sweat (Howie et al., 1996; Merrit and Brown, 1996). Compared to urine and sweat, hair has the advantage of long term memory; as a three-inch strand of human hair will give a six month history of the body chemistry (Wein-Schwaitz and Oderda, 2000).

The concentrations of metals such as $\mathrm{As}, \mathrm{Cd}, \mathrm{Hg}$ and $\mathrm{Pb}$ in hair samples has been reported to tend to correlate with the levels of these metals in internal organs (Maugh, 1978; Sharma and Kumar, 2004), this is one of the reasons why hair is used as a screening tool for forensic purposes. The ease of collecting hair samples compared to the blood of an animal also places hair ahead of blood for screening purposes. For instance, the determination of the level of $\mathrm{Cr}$ in the hair samples of diabetic patients is carried during the screening procedure, since low levels of chromium in the hair have been demonstrated in victims of juvenile-onset diabetes (Maugh, 1978).

This study reports the affinity of the components of blood of female albino rat (Rattus nervigicus) for bioaccumulation of $\mathrm{Cr}$ ions after 7 days of recovery from two weekly intraperitoneal administrations of 5.0 $\mathrm{mL}$ of $1.0 \mu \mathrm{g} / \mathrm{mL} \mathrm{K} \mathrm{K}_{2} \mathrm{Cr}_{2} \mathrm{O}_{7}$ solutionon day 1 and $1.0 \mathrm{~mL}$ of the solution on day 8; and to compare these to the bioaccumulation level in the fur of the animal model, in order to furnish additional scientific data for forensic analyses of industrial and environmental exposures to $\mathrm{Cr}$.

\section{MATERIALS AND METHODS}

\section{Intraperitoneal administration of $\mathrm{K}_{2} \mathrm{Cr}_{2} \mathrm{O}_{7}$} solution to albino rat

Twelve female albino rats (about 5-7 weeks old) of body weight ranging from 150 - $178 \mathrm{~g}$ were collected and bred in the animal house unit of Faculty of Pharmaceutical Science, Ahmadu Bello University, Zaria, Nigeria in May 2012. Six rats (E1 - E6) served as the experimental and six $(\mathrm{C} 1-\mathrm{C} 6)$ as control group. The two sets of rats were fed adequately with commercial rat pellets(Bendel Feeds and Flour Mill, Ewu, Nigeria) and tap water ad lib. The feed and water were analyzed for the level of chromium to serve as a baseline.

Five millilitre of $1.0 \mu \mathrm{g} / \mathrm{mL} \mathrm{K}_{2} \mathrm{Cr}_{2} \mathrm{O}_{7}$ solution - prepared by dissolution in Hank's solution ( $0.9 \% \mathrm{NaCl}$ solution) (Lori and Hanawa, 2001) - was injected intraperitoneally into the experimental rats in the morning of day 1 and $1 \mathrm{~mL}$ of the same solution on day 8 of the experiment. The responses to the exposures were observed from day 8-15; after which both groups were sacrificed by lethal dose of chloroform. The experiment conducted in this study was in accordance with the Ahmadu Bello University committee on animal use and care. And it was ensured that the animal received humane care according to the European Convention on Animal Care.

The concentration of the $\mathrm{Cr}$ solution was chosen based on the result of Omoniyi et al. (2010) in which the administration of $1.0 \mathrm{~mL}$ of $0.1,1.0$ or $5.0 \mu \mathrm{g} / \mathrm{mL}$ $\mathrm{K}_{2} \mathrm{Cr}_{2} \mathrm{O}_{7}$ solution - prepared by dissolution in Hank's solution - to female and male rats done intraperitoneally was used to determine the dose response $72 \mathrm{~h}$ after the administrations. An administration of $1.0 \mathrm{~mL}$ of 1.0 $\mu \mathrm{g} / \mathrm{mL} \mathrm{f} \mathrm{K}_{2} \mathrm{Cr}_{2} \mathrm{O}_{7}$ solution gave the optimum dose for an obscured physical effect in the animal model (Omoniyi et al., 2010).

The fur of the animal from both groups was collected using a cleaned pair of scissors. Blood $(3.5 \mathrm{~mL}$ ) was collected from both study groups using a $5 \mathrm{~mL}$ syringe after dissection of the animal. The blood was separated into erythrocytes, serum and blood plasma by centrifugation, thus:

\section{Separation of serum from whole blood}

A $1.0 \mathrm{~mL}$ aliquot of the blood sample in a microcentrifuge tube was positioned slantingly and undisturbed at room temperature for $2 \mathrm{~h}$ to allow the blood to clot. The blood was then centrifuged at 2000 rpm $(1650 \times \mathrm{g})$ for 20 minutes. The resulting supernatant which is the serum was measured and transferred into a beaker using a Pasteur pipette (http://www.nottingham.ac.uk/methods/serumseparatio nfro.html). 


\section{Separation of blood plasma and erythrocytes from whole blood}

To an aliquot of $2.5 \mathrm{~mL}$ fresh whole blood collected from each of the experimental and control rat in a glass tube, $0.1 \mathrm{~mL}$ of $2 \%$ potassium oxalate solution was added; the mixture was kept on ice to maintain a temperature of $4^{\circ} \mathrm{C}$. The blood was then centrifuged at $700 \times \mathrm{g} / 5$ minutes to separate the components. The resulting component was a clear solution of blood plasma in the upper phase of the centrifuge tube which was then separated by using a Pasteur pipette. The buffy coat, which is a thin layer of leukocytes (white blood cells), mixed with platelets in the middle. Erythrocytes (red blood cells) at the bottom of the centrifuge tube were carefully collected by using a Pasteur pipette to get rid of the leukocytes (Christain, 1978; David, 2011).

\section{Quality assurance and acid digestion}

Quality assurance of the atomic absorption machine was carried out by using four kidneys of the experimental rats; these were dried in an oven at a temperature of $60^{\circ} \mathrm{C}$ for about $24 \mathrm{~h}$. The dried kidneys were pulverized using an agate mortar and pestle. A 5.0 $\mathrm{mL}$ aliquot of $1.0 \mu \mathrm{g} / \mathrm{mL} \mathrm{K}_{2} \mathrm{Cr}_{2} \mathrm{O}_{7}$ solution was added to one half of the pulverized kidney in a beaker, while the other half had no addition of the solution.

Wet digestion of each of the $1.0 \mathrm{~mL}$ blood components, the fur obtained from the two groups of the animal and the kidney for spiking experiment was carried out using concentrated $\mathrm{HNO}_{3}$ and $\mathrm{HCl}$ in the ratio of $1: 3$ on a hotplate at $90^{\circ} \mathrm{C}$ for 10 minutes, while adding warm distilled water at the point of dryness. To the filtrate of each digest, distilled water was added in order to make it up to $10 \mathrm{~mL}$ in a volumetric flask. The level of $\mathrm{Cr}$ in each solution was then determined by atomic absorption spectrophotometry (Buck Scientific) at wavelength $357.9 \mathrm{~nm}$.

\section{RESULTS AND DISCUSSION}

\section{Behavioural pattern of the rats after injection}

On day 1 of the experiment, when $5 \mathrm{~mL}$ of $1 \mu \mathrm{g} / \mathrm{mL}$ $\mathrm{K}_{2} \mathrm{Cr}_{2} \mathrm{O}_{7}$ solution was administered, few hours later the experimental group looked dull and inactive compared to the control group. On the day 2 water intake of the experimental group was $25 \mathrm{~mL}$ which was relatively low compared to the $50 \mathrm{~mL}$ of the control group. This trend of inactivity of the experimental group continued for day 3 and 4 of the experiment with volume of water intake being $35 \mathrm{~mL}$ and $50 \mathrm{~mL}$ for the experimental and control group respectively on day 3, and $48 \mathrm{~mL}$ and 50 $\mathrm{mL}$ for the experimental and control group respectively on day 4 of the experiment. The same trend was observed for the experimental group in terms of the amount of feed intake which was less than the control group. The recovery period started from the late hours of day 4 and continued up to the early hours of day 8 , during which the experimental group became active and showed increase in the amount of water and feed intake, with the volume of water intake ranging from 50 $\mathrm{mL}-75 \mathrm{~mL}$ and $50 \mathrm{~mL}-73 \mathrm{~mL}$ for the experimental and control group respectively.

In the second week of the experiment i.e. on day 8 to day 15 during which $1.0 \mathrm{~mL}$ of $1 \mu \mathrm{g} / \mathrm{mL} \mathrm{K} \mathrm{K}_{2} \mathrm{Cr}_{2} \mathrm{O}_{7}$ solution was administered to the experimental group; there was a slightly different behavioural pattern for the experimental group. Few hours after the administration, the experimental group looked dull and inactive compared to the control group. Water and feed intake of the experimental group were less than the control group, with volume of water intake being $60 \mathrm{~mL}$ and 75 $\mathrm{mL}$ for the experimental and control group respectively. The same trend was observed on day 9 of the experiment. The recovery period for the second administration started during the late hours of day 9 and continued up to the end of the experiment at day 15 when the rats were sacrificed.

The finding led to the deduction that an intraperitoneal dose of $5 \mathrm{~mL}$ of $1.0 \mu \mathrm{g} / \mathrm{mL} \mathrm{K} \mathrm{Cr}_{2} \mathrm{O}_{7}$ solution to albino rat is a mild exposure dose with noticeable behavioural recovery after the fourth day of the intraperitoneal administration. However, intraperitoneal administration of $1 \mathrm{~mL} 1.0 \mu \mathrm{g} / \mathrm{mL} \mathrm{K} \mathrm{Cr}_{2} \mathrm{O}_{7}$ solution led to noticeable behavioural recovery after the second day of the administration.

Mean chromium concentration in components of blood and fur of experimental and control rats

The mean \% recovery for the spiking experiment carried out using kidney in order for quality assurance ranged from $78.9 \pm 0.23$ to 88.7.2 \pm 0.52 .

The mean level of total-Cr ions in the drinking water and feed given to the rats during the study were 0.0023 and $0.0036 \mu \mathrm{g} / \mathrm{mL}$ respectively; since these were below the allowable limits, the levels were insignificant to affect the accuracy of the results for the blood and fur. The mean chromium concentration $(n=6)$ in the serum, red blood cells (RBC), plasma and fur of the experimental and control groups depicted in Figure 1 indicated that for all the samples studied, the levels of $\mathrm{Cr}$ in the control group were lower than the experimental counterparts. The ranking for the mean level of total- $\mathrm{Cr}$ ions in the experimental followed the ranking, serum $>$ fur $>$ RBC $>$ plasma; while the control had the ranking serum $>$ fur $>$ plasma $>$ RBC. Following from Table 1,the highest variability in the level of total-Cr ions between the experimental and control group was found in serum having coefficient of variance (CV) being $68.32 \%$, this was closely followed by fur $(63.98 \%)$ while the lowest was in plasma $(4.02 \%)$. 
Bajopas Volume 8 Number 2 December, 2015

Table 1: Minimum and maximum levels of total- $\mathrm{Cr}$ ions in the components of blood and fur experimental and control rats following intraperitoneal administration of $\mathrm{K}_{2} \mathrm{Cr}_{2} \mathrm{O}_{7}$ solution

\begin{tabular}{lllll}
\hline Sample & $\begin{array}{l}\text { Minimum } \mathbf{C r} \\
(\boldsymbol{\mu g} / \mathbf{m L})\end{array}$ & $\begin{array}{l}\text { Maximum } \mathbf{~ r ~} \\
(\boldsymbol{\mu g} / \mathbf{m L})\end{array}$ & SD & CV (\%) \\
\hline Serum experiment & 9.633 & 15.650 & 0.726 & 68.32 \\
Serum control & 5.700 & 8.175 & 0.181 & \\
RBC experiment & 1.854 & 3.100 & 0.080 & 12.10 \\
RBC control & 1.345 & 3.460 & 0.072 & \\
Plasma experiment & 2.013 & 3.944 & 0.004 & 4.02 \\
Plasma control & 1.480 & 3.238 & 0.048 & \\
Fur experiment & 4.01 & 6.432 & 0.0078 & 63.98 \\
Fur control & 1.987 & 2.87 & 0.021 & \\
\hline
\end{tabular}

The information from CV indexes that the systemic $\mathrm{Cr}$ ions in rat has highest affinity for serum followed by the fur and least in plasma. This conforms to the assertion of Katharine and Stanley (1985) in the study undertaken in vivo and in vitro on the binding of metal ions as metal salts or as corrosion products $\left(\mathrm{Co}^{+2}, \mathrm{Ni}^{+2}\right.$, $\mathrm{Cr}^{+3}, \mathrm{Cr}^{+6}$ ) to tissues and cells; the findings reveal that most of the metal was in serum with some binding to cells. The most extensive binding to cells was recorded for $\mathrm{Cr}^{+6}$, which was the most strongly bound to red blood cells compared to white blood cells and tissue (Katharine and Stanley, 1985; Merrit and Brown, 1996). The presence of serum does not affect binding to the RBC and white blood cells.

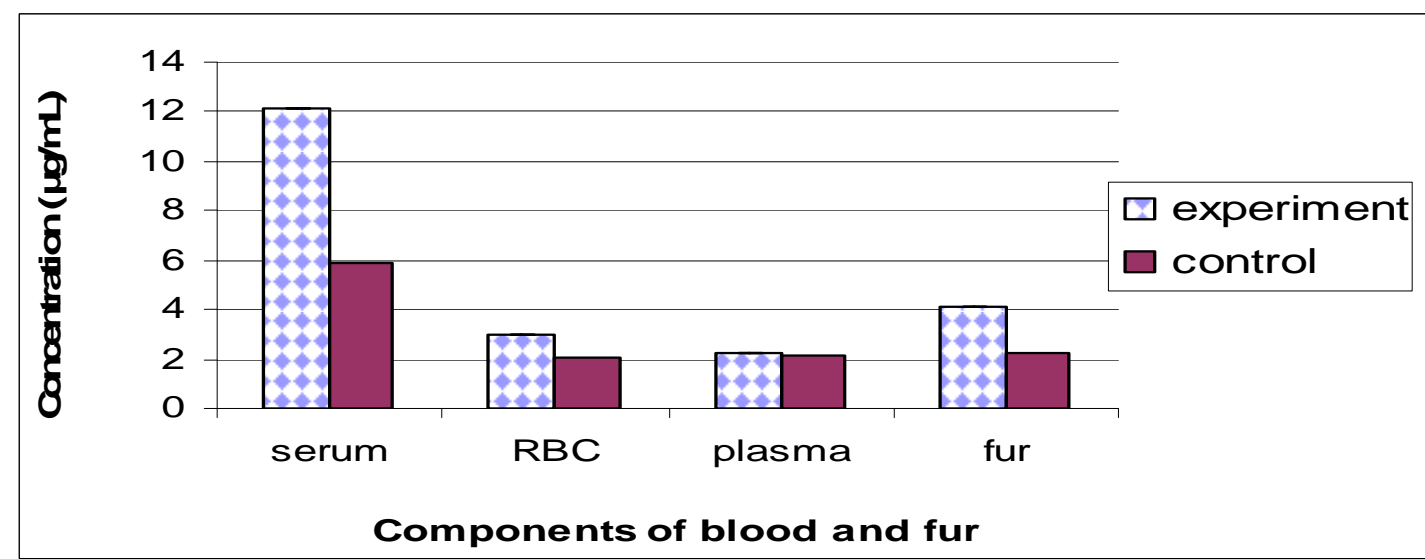

Figure 1: Mean concentrations of total-chromium ions in the components of blood and fur of experiment and control rats following intraperitoneal administration of $\mathrm{K}_{2} \mathrm{Cr}_{2} \mathrm{O}_{7}$ solution

The highest level of total-Cr ions recorded for serum in this study $(12.127 \pm 0.726 \mu \mathrm{g} / \mathrm{mL})$ is explained by the fact that the albumin and gamma globulin in serum has a very high propensity for binding metal ions. The blood $\mathrm{pH}$ of about 6.7 is basic to the isoelectric point of albumin (a protein with negative charges) so affinity for bioaccumulation of $\mathrm{Cr}^{+6}$ was highest in this component of blood; while the blood $\mathrm{pH}$ is acidic to the isoelectric point gamma globulin (a protein with negative charges; the amount of albumin in serum is about five times that of gamma globulin (Katharine and Stanley, 1985).

The mean level of $\mathrm{Cr}$ ions bioaccumulated in the experimental fur was $4.090 \pm 0.0078 \mu \mathrm{g} / \mathrm{mL}$; this was almost two-fold relative to the $2.23 \pm 0.021 \mu \mathrm{g} / \mathrm{mL}$ obtained in the control rats. The affinity can be traced to the absorption by the keratinous component of fur where the large number of disulphide bolds of keratin can form electrostatic bold with $\mathrm{Cr}^{+6}$ in the system; thus
$\mathrm{Cr}$ likely has a higher degree of protein binding (Maletin, 1988; Pautard, 1963).

Following from Figure 1, the serum level of total-Cr ion in the experimental animal was 3-fold that in fur, 4-fold that in RBC, and 6-fold that in plasma. For the control rat, the serum level of $\mathrm{Cr}$ ion was 3-fold than those recorded in fur, RBC and plasma.

Though, the animals were sacrificed after the intraperitoneal administration of $5.0 \mathrm{~mL}$ and $1.0 \mathrm{~mL}$ of the $1.0 \mu \mathrm{g} / \mathrm{mL} \mathrm{K} \mathrm{Cr}_{2} \mathrm{O}_{7}$ solution. It is anticipated that after the administration of the higher amount of $\mathrm{K}_{2} \mathrm{Cr}_{2} \mathrm{O}_{7}$ solution on day 1 , the plasma to erythrocyte (RBC) ratio of total chromium ions accumulated would decrease with increasing hexavalent chromium concentration administered intraperitoneally. In accordance to the finding of Corbett et al. (1998), the rate of excretion of $\mathrm{Cr}$ ion in the plasma is much more than the rate of excretion in the serum and red blood cells; because $\mathrm{Cr}$ binds to both transferrin and to a lesser degree albumin in plasma (Borguet et al., 1990; Vincent, 2000; 
Borguet et al., 1995). The plasma to erythrocyte ratio of total chromium ions accumulated decreased with increasing hexavalent chromium concentration administered intraperitoneally. This infers that the components of blood (serum, red blood cells) in the female animal are more prone to chromium toxicity than the plasma.

The $\mathrm{Cr}$ levels in the fur and serum were doubled due to the administration of $\mathrm{K}_{2} \mathrm{Cr}_{2} \mathrm{O}_{7}$ solution to the rats; this signals that the fur and serum can equally serve as specimen for detection of mild exposure to $\mathrm{Cr}$ (VI) during forensic investigation.

Duncan multiple range test (two-way) at $\mathrm{P}<0.05$ was used to investigate the statistical relationship that existed between the groups and the blood components/fur. There was high statistical increase in the total-Cr ions in the serum of the experimental rat compared to the control; likewise the level in the experimental fur was highly elevated compared to the control $(P<0.05)$. A slight significant increase was recorded in the level of $\mathrm{Cr}$ ion of the experimental RBC compared to the control. There was no statistical difference between the bioaccumulated total- $\mathrm{Cr}$ ions in plasma of the experimental to the control. There was significant difference in the $\mathrm{Cr}$ ion level in the serum compared to the other specimens studied for both groups $(P<0.05)$.

\section{Weight of rat to component bioaccumulation of Cr ions}

The mean body weight $(154.0 \mathrm{~g})$ of the control rats increased by $19 \%$ at day 15 ; this indicated a significant difference in weight during the 15-day experiment. The mean body weight of the experimental rats was $163 \mathrm{~g}$, this increased by $2 \%$ at day 15 . There was no significant difference in weight of the experimental rats during the 15-day experiment.

The total amount of chromium ions accumulated in the whole blood of the experimental rats, decreased as the weight increases. These was highest in rat $\mathrm{E} 1 \mathrm{of} \mathrm{Cr}$ ion concentration $24.79 \mu \mathrm{g} / \mathrm{mL}$ followed by E5 of $\mathrm{Cr}$ ion concentration $14.756 \mu \mathrm{g} / \mathrm{mL}$ of and least in E4 with concentration $12.33 \mu \mathrm{g} / \mathrm{mL}$; recording the initial weights $153 \mathrm{~g}, 178 \mathrm{~g}$ and $158 \mathrm{~g}$ and final weights $155 \mathrm{~g}, 162 \mathrm{~g}$ and $182 \mathrm{~g}$ respectively. The same trend was observed for the control group. These was highest in C4 of chromium ion concentration $16.873 \mu \mathrm{g} / \mathrm{mL}$ followed by C3 of chromium ion concentration $6.766 \mu \mathrm{g} / \mathrm{mL}$ and least in $\mathrm{C} 1$ having $\mathrm{Cr}$ concentration $6.587 \mu \mathrm{g} / \mathrm{mL}$; these had initial weights $146 \mathrm{~g}, 150 \mathrm{~g}, 167 \mathrm{~g}$ and final weights $156 \mathrm{~g}, 165 \mathrm{~g}$ and $172 \mathrm{~g}$ respectively.

The trend of the decrease in total-Cr ion concentration as weights increases might have resulted from the rats of smaller weights not been able to excrete effectively the intraperitoneally injected chromium solution. This

\section{REFERENCES}

Adya, N., Alam, M., Ravindranath, T., Mubeen, A. and Saluja, B. (2005). Corrosion of titanium dental implants: Literature review. Journal of Indian Prosthodontic Society,5: 126-131.

Amoikon, E.K., Fernandez, J.M, Southern, L.L, Thompson, D.L., Ward, T.L., Olcott, B.M. (1995). Effect of chromium tripicolinate on implies that the female rats with the larger weights did more effectively. This trend indicates that body weight has a negative correlation to $\mathrm{Cr}^{+6}$ bioaccumulation by whole blood of the animal.

\section{Conclusion}

High dose of chromium (VI) resulted to inactivity and less consumption of feed and water intake. While there was insignificant increase in the weights of the experimental group at day 15, the control group showed a significant weight gain of $19 \%$ at day 15 .

The ranking for the mean level of $\mathrm{Cr}$ ion in the experimental followed the ranking, serum $>$ fur $>$ RBC $>$ plasma; while the control had the ranking serum $>$ fur $>$ plasma $>$ RBC. The highest variability in the level of total-Cr ions between the experimental and control group was found in serum CV $68.32 \%$, this was closely followed by fur (63.98\%) and the lowest was in plasma $(4.02 \%)$. Therefore, this signals that serum and fur can serve as bio-indicator of the system level of $\mathrm{Cr}(\mathrm{VI})$. The serum level of $\mathrm{Cr}$ ion in the experimental animal was 3fold that in fur, 4-fold that in RBC, and 6-fold that in plasma. For the control rat the serum level of $\mathrm{Cr}$ ion was 3-fold than those recorded in fur, RBC and plasma. There was high statistical increase in the $\mathrm{Cr}$ ions in the serum of the experimental rat compared to the control; likewise the $\mathrm{Cr}$ level in the experimental fur was highly elevated compared to the control $(P<0.05)$. A slight significant increase was recorded in the level of $\mathrm{Cr}$ ion of the experimental RBC compared to the control. There was no statistical difference between the bioaccumulated $\mathrm{Cr}$ ions in plasma of the experimental to the control.

There is negative correlation between the body weight of the rat and $\mathrm{Cr}^{+6}$ bioaccumulated in whole blood samples.

The standard level of chromium in the serum, plasma and red blood cells by the National institute of health is in the range of 0.05 to $0.5 \mu \mathrm{g} / \mathrm{g}$ and the $\mathrm{WHO}$ international standards for drinking water recommend a maximum allowable concentration of $0.05 \mathrm{mg} / \mathrm{L}$ for chromium (VI). Although few adverse effect have been linked to high intakes of chromium, mean concentration of $\mathrm{Cr}$ (VI) found in the serum, red blood cells and plasma were $12.128 \mu \mathrm{g} / \mathrm{g}, 2.956 \mu \mathrm{g} / \mathrm{g}$ and $2.21 \mu \mathrm{g} / \mathrm{g}$ respectively, showing that concentration found in the animal model could still be detrimental to the animals. The study indicates that mild exposure of the physiological system to $\mathrm{Cr}$ ions could lead to mean accumulated levels of $\mathrm{Cr}$ ions that might pose health risk in the future. Therefore, it is recommended that there should be caution in the exposure of the body to $\mathrm{Cr}$ ions through ingestion, inhalation or dermal contact during occupational and domestic activities, even at mild doses.

growth hormones. Journal of Animal Science,58: 102-104.

Becker, N., Chang-Claude, J., Frentzel-Beyme, R. (1991). Risk of cancer for arc welders in the Federal Republic of Germany: Results of a second follow-up (1983-1988). Britanian Journal of Industrial Medicines,48: 675-683. 
Borguet, F., Cornelis R, Lameire N. (1990). Speciation of chromium in plasma and liver tissue of end stage renal failure patients on continuous ambulatory peritoneal dialysis. Biological Trace Elements Research,26: 449-460.

Borguet, F., Cornelis, R., Delanghe, J. (1995). Study of the chromium binding in plasma of patients on continuous ambulatory peritoneal dialysis. Clinical Chemimica Acta,238: 71-84.

Christain, G.D. (1978). Analytical Chemistry. Vol. II, Pp. 553-557.

Corbett, G.E., Finley, B.L., Paustenbach, D.J. (1998). Systemic uptake of chromium in human volunteers following dermal contact with hexavalent chromium (22 mg/L).J. Exposure Analytical and Environmental Epidemiology, 7(2): 179-189.

David, R.C. (2011). Rice University experimentalbiosciences. Blood and Erythrocyte Fractionation.

Ecological Analysts, Inc. (1981). The sources, chemistry, fate, and effects of chromium in aquatic environments. American Petroleum Institute. 2101 L St., N.W., Washington, DC 20037. Pp. 207.

Howie, D.W., Rogers, S.D., McGee, M.A., Haynes, D.R. (1996). Biologic effects of cobalt chrome in cell and animal models. Clinical Orthopaedic Related Research,329S: S217-S232.

Katharine, M., Stanley, A.B. (1985). Biological effects of corrosion products from metals: Corrosion and degradation of implant materials. second symposium, American Society for Testing and Materials, Philadelphia, pp. 195-207.

Kempson, I.M., Skinner, W.M., Kirkbride, K.P. (2007). The occurrence and incorporation of copper and zinc in hair and their potential as bioindicators: a review. Journal of Toxicology and Environmental Health,B 10: 611-622.

Kortenkamp, A. (1997): Problems in the biological monitoring of chromium (VI) exposed individuals. Biomarkers, 2:73-80.

Langard, S., Norseth, T. (1979). Chromium. In: Friberg, L., Nordberg, G.F., Vouk, V.B. (eds.). Handbook on the toxicology of metals. Elsevier/North Holland Biomedical Press. Pp. 383-397.

Lori, J.A. and Hanawa, T. (2001). Adsorption characteristics of albumin on gold and titanium in Hank's solution using EQCM. Corrosion Science, 43: 2111.

Maletin, Y.A. (1988). Institute of general and inorganic chemistry. Academy of Sciences of the Ukranian SSR, Kiev. Translated from Teoreticheskaya I Eksperimental'naya Khimiya, 24 (4): 450-455.
Maugh, T.N. (1978). Hair: a diagnostic tool to complement blood serum and urine. Science, 202:1271-1273.

Merrit, K., Brown, S.A. (1996). Distribution of cobaltchromium wear corrosion products and biologic reactions. Clinical Orthopaedics, 329S: S233-S243.

Methods of serum separation. Accessed 27 March 2012. Available:

http://www.nottingham.ac.uk/methods/serums eparationfro.html.

Omoniyi, K.I., Ekwumemgbo, P.A., Aligwo, C., Balogun, M., Adewusi, A.M. (2010). Effect of gender on the dose accumulation of chromium ions in organs of Rattusnervigicus. Electronic Journal of Environment, Agriculture and Food Chemistry, 9(4): 735-741.

Pautard, F.G.E. (1963). Mineralization of keratin and its comparison with the enamel matrix. Nature, 199: $531-535$

Post, M.A., Campbell, P.G. (1980). Lead chromate pigments-a literature survey on environmental and toxic effects. U.S. Dep. Comm. National Bureau of Standard Report, NBSIR 80-1974. Pp. 38.

Ronald, E. (1986). Chromium hazards to fish, wildlife, and invertebrates: a synoptic review. Contaminant Hazard Review of Biological Report, 85(1.6) January(6).

Sharma, R. and Kumar, A. (2004). Trace element contents in human head hair of residents from Agra City (India). Bulletin of Environmental Contamination and Toxicology, 72: 530-534.

Steven, J.D., Davies, L.J, Stanley, E.K, Abbott, R.A., Ihnat, M., Bidstrup, L., Jaworski, J.F. (1976). Effects of chromium in the Canadian environment. Natural Resources Council Canada, NRCC No. 15017. NRCC/CNRC, Ottawa, Canada, K1A OR6. Pp.168.

Taylor, F.G. (Jr.), Parr, P.D. (2002). Distribution of chromium in vegetation and small mammals adjacent to cooling towers. Journal of Tenn Academy of Science, 53:87-91.

Vincent, J.B. (2000). The biochemistry of chromium. Journal of Nutrition,130: 715-718.

Wein-Schwaitz, W., Oderda, G.M. (2000). Clinical toxicology. In: Therapeutics, drug and disease management. (7th Ed.). Baltimore Press, Wicliams and Wilkins. Pp. 51.

Wiegand, H.J., Ottenwalder, H., Bolt, H.M. (1985). Fast uptake kinetics in vitro of ${ }^{51} \mathrm{Cr}$ (VI) by red blood cells of man and rat. Archives of Toxicology,57(1): 31-34.

Yamaguchi, S., SanoK, S.N. (1983). On the biological half-time of hexavalent chromium in rats. Industrial Health, 21:25-34.

Yasuko, T., Takao, H., Daisuke, K., Masahiro, E. (2006). Corrosion of stainless steel sternal wire after long-term implantation. Journal of Artificial Organs,10(2):145-148. 